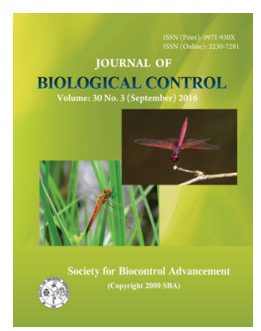

\title{
Diversity and population dynamics of Odonata (Insecta: Odonata) in rice growing area of central Gujarat
}

\author{
V. B. ROHMARE ${ }^{*}$, DARSHANA M. RATHOD, and B. M. PARASHARYA \\ AINP on Agricultural Ornithology, Anand Agricultural University, Anand - 388110, Gujarat, India \\ *Corresponding author E-mail: rohmarevb@gmail.com
}

\begin{abstract}
Odonates diversity was studied in Paddy field of central Gujarat during 2012 to 2015. Total 39 species belonging to 25 genera, under six families and two suborders were recorded. Total 17 species of Zygoptera (damselflies) and 22 species of Anisoptera (dragonflies) were recorded. Community structure and population dynamics of adult odonates were studied at Lingda village during July to December, 2012 through monitoring their population by point count method on three microhabitats (paddy field, village pond and fish farm). Total seventeen species were encounterd in the point count. Diversity index (H') was highest (2.13) for paddy fields followed by fish farm (2.07) and village pond (1.99). Evenness value of the odonates also ranged between 0.7 and 0.8. Total four species (Viz. Ditch Jewel (25.0\%), Green Marsh Hawk (17\%), Ruddy Marsh Skimmer and Coromandal Marsh Dart (16\% each) were dominant species in all three microhabitats. Both the suborders Anisoptera (dragonfly) and Zygoptera (damselfly) showed similar trend of population fluctuation during the study. Relative abundance was higher and remained constant during 4th week of September to $2^{\text {nd }}$ week of October.
\end{abstract}

KEY WORDS: Central Gujarat, damselfly, diversity, dragonfly, odonates, paddy crop (Oryza sativa L.), population dynamics

(Article chronicle: Received:15-07-2016; Revised: 11-09-2016; Accepted: 18-09-2016)

\section{INTRODUCTION}

Globally 5,952 species of odonates are known and of this 474 species in 142 genera and 18 families exist in India (Subramanian, 2014). Information about the odonates of Gujarat state is documented by Prasad (2004), Rohmare et al. (2015) and Rathod et al. (2016a; 2016b; 2016c). Total 42 species of odonates are recorded from Central Gujarat and 80 from entire Gujarat state. Though the entire order is predacious and hence important biocontrol agents of insect pests (Rathod and Parasharya, 2014; 2015), there is no information (species list) available on the odonates available in the paddy crop agro-ecosystems in Gujarat. Even at national level, hardly something is known about the odonate diversity in paddy crop agroecosystem (Gunathilagaraj et al., 1999; Kandibane et al., 2003; 2005; Anbalagan et al., 2013; Sathe and Shinde, 2014).

Several pests cause damage and yield loss on paddy crop (Datta and Khush, 2002). Pesticides can control many of the rice pests, but because of environmental risks, crop infection and killing of beneficial insects (natural enemies and pollinators) are not efficient and safe method (Khan et al., 1991). There are several natural predators in the rice fields that if conserved, can play an effective role in decreasing the pest population density (Mohyuddin, 1990; Bonhofet al., 1997). Larva and adults Odonata are considered efficient predators in the rice fields (Heinrichs, 1994; Alonso Mejia and Marquez, 1994). The carnivorous and voracious odonate larvae occupy at the apex of food chain of invertebrate life in aquatic ecosystem (Siregar et al., 2010).

The quantitative field data necessary for understanding odonate population dynamics in paddy crop are scarce. To fill up the gaps in our knowledge about the diversity of Odonata in the paddy crop agro-ecosystems of Central Gujarat, the present study was planned. Anand district of Central Gujarat is having its rice fields irrigated by the canals of Mahi right bank canal system (MRBS) and associated storage tanks, should be very rich in odonate diversity. Paddy (Oryza sativa) crop agro-ecosystem is the ideal habitat for the dragonflies. Since the paddy is being grown in almost all the districts of Central Gujarat, odonate diversity was expected to be very high. Dragonflies are known as the predators of small insects and hence it was worth identifying each species occurring in paddy crop agroecosystem and their population dynamics during the crop period. 


\section{MATERIALS AND METHODS}

This study was carried out in the agricultural landscape of Central Gujarat during July 2011 to December, 2015.

\section{Study area}

Anand District is situated between $22^{\circ} 57^{\prime}(\mathrm{N})$ Latitude and $72^{\circ} 93^{\prime}$ (E) Longitude in the central part of Gujarat State. The total area of the district is 2, 94,751 hectares which is 1.52 per cent area of Gujarat State. The district comprises of eight tahsils from the revenue record. Population dynamics of adult odonates was studied at Lingda village (22.700006N, 73.116694E) of Umreth tahsil in Anand district.

Kheda and Anand districts which are in the command area of MRBS lies between two major Rivers, Mahisagar on the eastern side and Sabarmati on the western side. The northen part of the district has common boundary with Kheda district. Ahmedabad district is on the western side of River Sabarmati and Vadodara on the eastern side of River Mahisagar. The southern fringe of Central Gujarat is attached to the Gulf of Khambhat. The Central Gujarat is plain land with some hilly area of Dahod and Panchmahal districts. The region has typical fertile soil popularly known as "Goradu soil" with loamy sand of alluvial origin. The sandy loam soil is known for its productivity. Irrigation facility through Mahi Right Bank Canal is available since 1960 in Kheda and Anand districts and hence, intensive cropping is practiced throughout the year. Complex network of irrigation canals and associated tanks, village ponds and paddy fields provide ideal habitats for the odonates. Irrigated paddy (Oryza sativa L.) is cultivated in 4,056 ha area of Anand district during Southwest monsoon (June to September). About 13,090 ha land cover of Anand district is under agriculture and no area is classified as protected or forest land. Umreth tahsil in which population dynamics of odonate was monitored, about $30 \%$ land was under paddy cultivation.

\section{General inventory}

This study was done during 2012 to 2015 . Intensive surveys were done during South-West monsoon (July to November). Adult, free flying Odonates were collected from the shallow edge of the wetland using standard insect net. The specimens were preserved in $70 \%$ alcohol and kept separate by placing them in envelopes, labelled properly with details like species, date and place of collection. Extra specimens were preserved dry following standard procedure.
The specimens were identified with the help of photographic guides (Emiliyamma et al., 2005; Subramanian, 2009; Nair, 2011) and a suitable taxonomic book (Fraser 1933, 1934, 1936). The scientific names are adopted from the revised nomenclature by Subramanian (2014). Identification of specimens was confirmed by Dr. S. S. Talmale at Zoological Survey of India, Jabalpur.

\section{Population dynamics and diversity of odonates}

Population dynamics is a study of changes in species composition and their number with reference to time interval. To study the changes taking place in their population and diversity over a time frame, "point count method" was adopted for sampling the area. Study was carried out by using the following census method during July to December 2012. A weekly point count were done at the edge of a (1) wetland (village pond), (2) fish farm and (3) across the paddy fields during the monsoon and post-monsoon periods (July to December 2012) following the protocol of Smallshire and Beynon (2010).

Odonates were counted at fifteen points in each microhabitat at weekly interval. At a fixed point, Adult Odonates observed within $3 \mathrm{~m}$ radius of visual field were observed and counted species wise minimum $10 \mathrm{~m}$ distance was maintained between two points. Odonate counts were taken during 9.00 to 12.00 hours in the morning (as they are known to be active during morning/ evening hours) on cloudless day, preferably on Sundays. Counts on all the microhabitats were done on same day. Visual identification was confirmed by collecting a few specimens. Changes taking place in the number of Odonates encountered during point count served as an index of population dynamics. Relative abundance (\%) of the species and rate of encounter or frequency of occurrence ( $\% \mathrm{O}$ and $\%$ fi) were worked out to determine species dominance and Important Value Index (Tiple et al., 2012; Obrtel and Holisova, 1974). Species diversity index using Shannon-Weiner formula (Shannon, 1948) and equitability worked out (Krebs, 1975) for each time period as well as entire cropping season.

\section{RESULTS AND DISCUSSION}

\section{General inventory in paddy fields}

Total 39 species belonging to 25 genera, under six families and two suborders were recorded from paddy crop in Central Gujarat. Total 17 species of Zygoptera (damselflies) and 22 species of Anisoptera (dragonflies) were recorded. This list does not include species which are habitat specialist occurring in streams, rivers, forest and salty wetland. Zygoptera was represented by three families and Anisoptera was represented by three families (Table 1). 
Table 1. Odonata of rice growing areas of Central Gujarat

\begin{tabular}{|c|c|}
\hline Taxon & Common name \\
\hline \multicolumn{2}{|l|}{ Suborder: Zygoptera } \\
\hline \multicolumn{2}{|l|}{ Superfamily :Lestoidea } \\
\hline \multicolumn{2}{|l|}{ Family :Lestidae } \\
\hline \multicolumn{2}{|l|}{ Lestes thoracicus Laidlaw, 1920} \\
\hline Lestes umbrinus Selys, 1891 & Brown spreadwing \\
\hline Lestes viridulus Rambur, 1842 & Emerald-striped spreadwing \\
\hline \multicolumn{2}{|l|}{ Superfamily: Coenagrionoidea } \\
\hline \multicolumn{2}{|l|}{ Family: Platycnemididae } \\
\hline Copera marginipes (Rambur, 1842) & Yellow bush dart \\
\hline \multicolumn{2}{|l|}{ Elattoneura nigerrima (Laidlaw, 1917) } \\
\hline \multicolumn{2}{|l|}{ Superfamily: Coenagrionoidea } \\
\hline \multicolumn{2}{|l|}{ Family: Coenagrionidae } \\
\hline Agriocnemis pygmaea (Rambur, 1842) & Pigmy dartlet \\
\hline Ceriagrion coromandelianum (Fabricius, 1798) & Coromandal marsh dart \\
\hline Enallagma cyathigerum (Charpentier, 1840) & Common blue damselfly \\
\hline Ischnura aurora (Brauer, 1865) & Golden dartlet \\
\hline Ischnura elegans (Vander Linden, 1823) & Common blue tail \\
\hline Ischnura nursei (Mortan, 1907) & Pixie dartlet \\
\hline Ischnura senegalensis (Rambur, 1842) & Senegal golden dartlet \\
\hline Paracercion malayanum (Selys, 1876) & Malay lily squatter \\
\hline Pseudagrion decorum (Rambur, 1842) & Three- striped blue dart \\
\hline Pseudagrion hypermelas Selys, 1876 & Violet-striped blue dart \\
\hline Pseudagrion microcephalum (Rambur, 1842) & Blue grass dartlet \\
\hline Pseudagrion rubriceps Selys, 1876 & Saffron-faced blue dart \\
\hline \multicolumn{2}{|l|}{ Suborder: Anisoptera } \\
\hline \multicolumn{2}{|l|}{ Super family: Aeshnoidea } \\
\hline \multicolumn{2}{|l|}{ Family: Aeshnidae } \\
\hline Anax guttatus (Burmeister, 1839) & Blue-tailed green darner \\
\hline Anax immaculifrons Rambur, 1842 & Blue darner \\
\hline \multicolumn{2}{|l|}{ Superfamily: Gomphoidea } \\
\hline \multicolumn{2}{|l|}{ Family: Gomphidae } \\
\hline Ictinogomphus rapax (Rambur, 1842) & Common clubtail \\
\hline \multicolumn{2}{|l|}{ Superfamily: Libelluloidea } \\
\hline \multicolumn{2}{|l|}{ Family: Libellulidae } \\
\hline Acisoma panorpoides (Rambur, 1842) & Trumpet tail \\
\hline Brachydiplax sobrina (Rambur, 1842) & Little blue marsh hawk \\
\hline Brachythemis contaminata (Fabricius, 1793) & Ditch jewel \\
\hline Crocothemis servilia (Drury, 1770) & Ruddy marsh skimmer \\
\hline Diplacodes lefebvrii (Rambur, 1842) & Black ground skimmer \\
\hline Diaplacodes trivialis (Rambur, 1842) & Ground skimmer \\
\hline Neurothemis tullia (Drury, 1773) & Pied- paddy skimmer \\
\hline Orthetrum luzonicum (Brauer, 1868) & Tricoloured marsh hawk \\
\hline Orthetrum pruinosum neglectum (Rambur, 1842) & Crimson- tailed marsh hawk \\
\hline Orthetrum sabina (Drury, 1770) & Green marsh hawk \\
\hline Orthetrum taeniolatum (Schneider, 1845) & Taeniolate marsh hawk \\
\hline Pantala flavescens (Fabricius, 1798) & Wandering glider \\
\hline Rhyothemis variegata (Linnaeus, 1763) & Common picture wing \\
\hline Tholymis tillarga (Fabricius, 1798) & Coral-tailed cloud wing \\
\hline Tramea basilaris burmeisteri Kirbyi, 1889 & Red marsh trotter \\
\hline Trithemis aurora (Burmeister, 1839) & Crimson marsh glider \\
\hline Trithemis pallidinervis (Kirby, 1889) & Long-legged marsh glider \\
\hline Urothemis signata (Rambur, 1842) & Greater crimson glider \\
\hline Zyxomma petiolatum Rambur, 1842 & Brown dusk hawk \\
\hline
\end{tabular}


Population dynamics, diversity and community structure of odonate

\section{Paddy crop agro-ecosystem}

Paddy is the only crop grown in the agricultural landscape of Lingda village during Kharif season. The fields were inundated with canal water in mid July for transplanting paddy saplings. Relative abundance of odonates on first week of observation was low compared to other two microhabitats. However, growth of the population size was relatively faster than other microhabitats. Relative abundance remained constant during $4^{\text {th }}$ week of September to $2^{\text {nd }}$ week of October (one month). After $3^{\text {rd }}$ week of October; crash in population size was sharp. The paddy crop was harvested in mid November and as a result relative abundance of odonates was negligible. Thereafter, odonates abundance remained zero throughout study period (Table 2 ).

\section{Village pond}

Due to fresh rain in early July, the village pond was having full water and some odonates were present. During initial six weeks, their abundance ranged between 2 to 4 percent but the abundance started increasing from $2^{\text {nd }}$ week of September (R.A.7\%) Relative abundance reached to its peak $(12 \%)$ during $2^{\text {nd }}$ week of October. It took twelve long weeks to reach the peak of population abundance but it crashed down to $1 \%$ within next five weeks. Odonate population remained below one percent during $3^{\text {rd }}$ week of November to $4^{\text {th }}$ week of December 2012 and then after they were totally missing from the village pond (Table 2 ).

\section{Fish farm}

On fish farm, total sixteen species were recorded. Trumpet Tail was a unique species. Odonates abundance was low in the initial three weeks but from $4^{\text {th }}$ week $\left(3^{\text {rd }}\right.$ week of August) it started increasing, highest relative abundance $(10.31 \%)$ was recorded in $2^{\text {nd }}$ week of October. This trend of population growth was similar to the trend observed on village pond. By $1^{\text {st }}$ week of December, relative abundance became less than one percent. Contrasting to other two microhabitats, at least one odonate was encoun-

Table 2. Population dynamics of odonates at weekly interval expressed as Relative abundance (\%) in paddy crop agroecosystem at Lingda, Anand district, Gujarat

\begin{tabular}{|c|c|c|c|c|c|c|c|c|c|}
\hline \multirow{3}{*}{ Sr. No. } & \multirow{3}{*}{ Weeks } & \multicolumn{8}{|c|}{ Microhabitats } \\
\hline & & \multicolumn{2}{|c|}{ Paddy field } & \multicolumn{2}{|c|}{ Village pond } & \multicolumn{2}{|c|}{ Fish farm } & \multicolumn{2}{|c|}{ Total } \\
\hline & & No. & $\%$ & No. & $\%$ & No. & $\%$ & No. & $\%$ \\
\hline 1 & 28-Jul-12 & 017 & 01.54 & 048 & 03.84 & 030 & 02.05 & 095 & 02.49 \\
\hline 2 & 04-Aug-12 & 028 & 02.54 & 031 & 02.48 & 040 & 02.73 & 099 & 02.59 \\
\hline 3 & 11-Aug-12 & 023 & 02.09 & 029 & 02.32 & 033 & 02.25 & 085 & 02.23 \\
\hline 4 & 18-Aug-12 & 035 & 03.18 & 042 & 03.36 & 056 & 03.82 & 133 & 03.49 \\
\hline 5 & 25-Aug-12 & 065 & 05.90 & 028 & 02.24 & 071 & 04.85 & 164 & 04.30 \\
\hline 6 & 01-Sep-12 & 057 & 05.18 & 050 & 04.00 & 060 & 04.10 & 166 & 04.35 \\
\hline 7 & 08-Sep-12 & 094 & 08.54 & 087 & 06.95 & 117 & 07.99 & 298 & 07.81 \\
\hline 8 & 15-Sep-12 & 071 & 06.45 & 064 & 05.12 & 075 & 05.12 & 210 & 05.50 \\
\hline 9 & 22-Sep-12 & 117 & 10.63 & 088 & 07.03 & 089 & 06.08 & 294 & 07.70 \\
\hline 10 & 29-Sep-12 & 120 & 10.90 & 116 & 09.27 & 140 & 09.56 & 376 & 09.85 \\
\hline 11 & $06-O c t-12$ & 113 & 10.26 & 125 & 09.99 & 141 & 09.62 & 379 & 09.93 \\
\hline 12 & 13 -Oct-12 & 114 & 10.35 & 155 & 12.39 & 151 & 10.31 & 420 & 11.01 \\
\hline 13 & $20-$ Oct-12 & 077 & 06.99 & 123 & 09.83 & 129 & 08.81 & 329 & 08.62 \\
\hline 14 & $27-$ Oct-12 & 080 & 07.27 & 110 & 08.79 & 127 & 08.67 & 317 & 08.31 \\
\hline 15 & 03-Nov-12 & 045 & 04.09 & 070 & 05.60 & 088 & 06.01 & 203 & 05.32 \\
\hline 16 & 10-Nov-12 & 023 & 02.09 & 032 & 02.56 & 050 & 03.41 & 105 & 02.75 \\
\hline 17 & 17-Nov-12 & 011 & 01.00 & 013 & 01.04 & 020 & 01.37 & 044 & 01.15 \\
\hline 18 & 24-Nov-12 & 007 & 00.64 & 011 & 00.87 & 021 & 01.43 & 039 & 01.02 \\
\hline 19 & 01-Dec-12 & 004 & 00.37 & 012 & 01.00 & 010 & 00.68 & 026 & 00.68 \\
\hline 20 & 08-Dec-12 & 000 & 00.00 & 006 & 00.47 & 005 & 00.34 & 011 & 00.29 \\
\hline 21 & 15-Dec-12 & 000 & 00.00 & 009 & 00.71 & 009 & 00.61 & 018 & 00.47 \\
\hline 22 & 22-Dec-12 & 000 & 00.00 & 002 & 00.15 & 001 & 00.06 & 003 & 00.08 \\
\hline 23 & 29-Dec-12 & 000 & 00.00 & 00 & 00.00 & 001 & 00.06 & 001 & 00.03 \\
\hline 24 & 05-Jan-13 & 000 & 00.00 & 00 & 00.00 & 001 & 00.06 & 001 & 00.03 \\
\hline \multirow[t]{2}{*}{25} & 12-Jan-13 & 000 & 00.00 & 00 & 00.00 & 000 & 00.00 & 000 & 00.00 \\
\hline & Total & 1101 & & 1251 & & 1465 & & 3816 & \\
\hline
\end{tabular}


tered during point count and a few others were seen flying at distance, outside point count radius (Table 2).

\section{Composite picture of population fluctuation of odonates at Lingda village}

During twenty five week study, total 3816 adult odonates were recorded on three microhabitats. There was no water in the Paddy fields as well as Fish farm during preceding summer, however; some water was available in the village pond and irrigation canal. Hence, wetland habitats of the village were inundated only in mid July with onset of Southwest monsoon. The fish farm and paddy fields were also flooded in mid July for fish culture and paddy cultivation respectively. Hence, the odonates recorded during first observation (28 ${ }^{\text {th }}$ July 2012) can be considered as initial adult population. Their population slowly increased and reaches to about eight percent in seventh week $\left(8^{\text {th }}\right.$ September 2012). It reached to its peak in $12^{\text {th }}$ week $\left(13^{\text {th }}\right.$ October 2012). A sharp decline in the population was recorded from $27^{\text {th }}$ October $\left(14^{\text {th }}\right.$ week $)$ and it reached to just one percent by $17^{\text {th }}$ November 2012 . This sharp decline in the population was attributed to decline in the inundated area in all three microhabitats. Odonate population remained below one percent during December 2012 and January 2013. During February to April 2013, odonates were not encountered during point count but were present is small number in the environment (Table 2, Fig. 1).

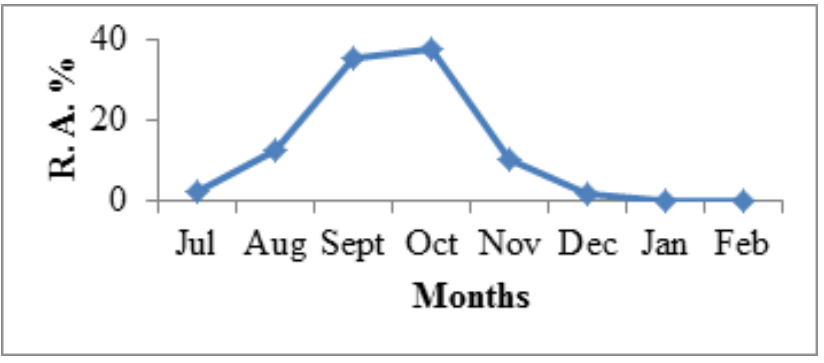

Fig. 1. Relative abundance of Odonates (Total) in the wetland landscape of Lingda.

An increase in Odonate population was positively correlated with flooding of the microhabitats because entire order is amphibious and requires aquatic habitat for breeding. The paddy dominated landscape remained inundated for more than three months which provided ideal breeding condition to the odonates.

Increase and decrease in odonate abundance followed similar trend in all three microhabitats. The paddy fields and fish- farms were drained and hence became dry by November. On the contrary, the village pond had sufficient water, but still showed similar decline in abundance.

\section{Diversity and community structure of odonates}

Diversity and community structure of odonates was studied at paddy growing area of Lingda village through

Table 3. Community structure of odonates species in paddy crop agroecosystem at Lingda, Anand district, Gujarat

\begin{tabular}{|c|c|c|c|c|c|c|c|c|c|}
\hline \multirow{3}{*}{$\frac{\text { Sr. No. }}{1 .}$} & \multirow{3}{*}{ Species } & \multicolumn{8}{|c|}{ Microhabitats } \\
\hline & & \multicolumn{2}{|c|}{ Paddy field } & \multicolumn{2}{|c|}{ Village pond } & \multicolumn{2}{|c|}{ Fish farm } & \multicolumn{2}{|r|}{ Total } \\
\hline & & No. & $\%$ & No. & $\%$ & No. & $\%$ & No. & $\%$ \\
\hline 2. & Ceriagrion coromandelianum & 171 & 12.00 & 199 & 16.00 & 240 & 16.00 & 610 & 15.98 \\
\hline 3. & Enallagma cyathigerum & 053 & 05.00 & 052 & 04.00 & 058 & 04.00 & 163 & 04.27 \\
\hline 4. & Ischnura aurora & 019 & 01.73 & 000 & 00.00 & 000 & 00.00 & 019 & 00.50 \\
\hline 5. & Ischnura elegans & 006 & 00.55 & 013 & 01.00 & 009 & 00.61 & 028 & 00.73 \\
\hline 6. & Ischnura senegalensis & 097 & 09.00 & 100 & 08.00 & 121 & 08.00 & 318 & 08.33 \\
\hline 7. & Pseudagrion microcephalum & 061 & 06.00 & 106 & 08.00 & 067 & 04.00 & 234 & 06.13 \\
\hline 8. & Pseudagrion rubriceps & 000 & 00.00 & 020 & 02.00 & 011 & 00.75 & 031 & 00.81 \\
\hline 9. & Ictinogomphus rapax & 000 & 00.00 & 002 & 00.15 & 004 & 00.29 & 006 & 00.16 \\
\hline 10. & Acisoma panorpoides & 000 & 00.00 & 000 & 00.00 & 039 & 03.00 & 039 & 01.02 \\
\hline 11. & Brachythemis contaminata & 198 & 18.00 & 379 & 30.00 & 368 & 25.00 & 945 & 24.76 \\
\hline 12. & Crocothemis servilia & 199 & 18.00 & 165 & 13.00 & 232 & 16.00 & 596 & 15.61 \\
\hline 13. & Diaplacodes trivialis & 030 & 02.72 & 002 & 00.16 & 012 & 00.82 & 044 & 01.15 \\
\hline 14. & Orthetrum luzonicum & 021 & 02.00 & 000 & 00.00 & 012 & 00.82 & 033 & 00.86 \\
\hline 15. & Orthetrum sabina & 201 & 19.00 & 180 & 14.00 & 244 & 17.00 & 625 & 16.37 \\
\hline 16. & Pantala flavescens & 005 & 00.46 & 012 & 01.00 & 008 & 00.55 & 025 & 00.65 \\
\hline 17. & Rhyothemis variegata & 006 & 00.55 & 000 & 00.00 & 005 & 00.34 & 011 & 00.29 \\
\hline 18. & Trithemis pallidinervis & 034 & 03.00 & 021 & 02.00 & 035 & 02.00 & 090 & 02.36 \\
\hline & Total & 1101 & & 1251 & & 1465 & & 3816 & \\
\hline
\end{tabular}


monitoring their population dynamics on three microhabitats. Though, total 39 odonate species were recorded in paddy crop agroecosystem of Central Gujarat, only seventeen species were recorded in the point count method employed for this study. Sixteen species were recorded on fish farm, forteen species were recorded on paddy fields whereas least number (13) of species richness was on village pond (Table 3). Trumpet Tail (Acisoma panorpoides) was a unique species recorded on fish pond. In paddy fields, Golden Dartlet (Ischnura aurora) was a unique species (Table 3).

Species diversity index reflects species richness and their relative abundance. In present study, diversity index was highest (2.13) for paddy fields followed by fish farm (2.07) and least on village pond (1.99). Evenness value of the odonates also ranged between 0.7 and 0.8 (Table 4). Overall diversity index (H') for paddy crop agroecosystem was 2.10 with 0.741 evenness $(\mathrm{J})$.

Table 4. Diversity indices of Odonata on different microhabitats at Lingda

\begin{tabular}{llll}
\hline Microhabitats & $\begin{array}{l}\text { Species } \\
\text { Richness (S) }\end{array}$ & $\begin{array}{l}\text { Species Di- } \\
\text { versity (H') }\end{array}$ & Evenness (E) \\
\hline Fish Farm & 16 & 2.07 & 0.731 \\
Paddy Field & 14 & 2.13 & 0.807 \\
Village Pond & 13 & 1.99 & 0.776 \\
Over all & 17 & 2.10 & 0.741 \\
\hline
\end{tabular}

\section{Community structure}

Amongst sixteen species recorded on fish farm. Trumpet Tail was a unique species, which was not recorded on other two microhabitats. Only four species were dominant: Ditch Jewel (25.0\%), Green Marsh Hawk (17\%), Ruddy Marsh Skimmer and Coromandal Marsh Dart (16\% each) (Table 3).

On paddy fields, total fourteen species were recorded. Golden Dartlet $(1.73 \%)$ was a unique species in paddy fields. Unlike fish farm, the same four species were dominant, however, values of their relative abundance varied (Table 3).

Village pond had least species richness (13) compared to other two microhabitats. Here, absence of four species was more prominent feature than presence of any unique species. The same four species were dominant on village pond too but relative abundance of Ditch Jewel was thirty percent (30\%); highest amongst three microhabitats (Table $3)$.

To get a composite picture of community structure of odonates within agricultural landscape of Lingda vil- lage, data of all the microhabitats were merged and overall relative abundance of each species was worked out (Table $3)$. Though seventeen species were recorded during point count in the area, eight species were less than one persent in abundance. Amongst the four dominant species in the agriculture landscape (Fig. 2), Ditch Jewel was the most dominant $(25 \%$ R. A.) whereas remaining three species were represented equally (Fig. 2). Other two notable species were Senegal Golden Dartlet (8.33\%) and Blue Grass Dartlet $(6.13 \%)$

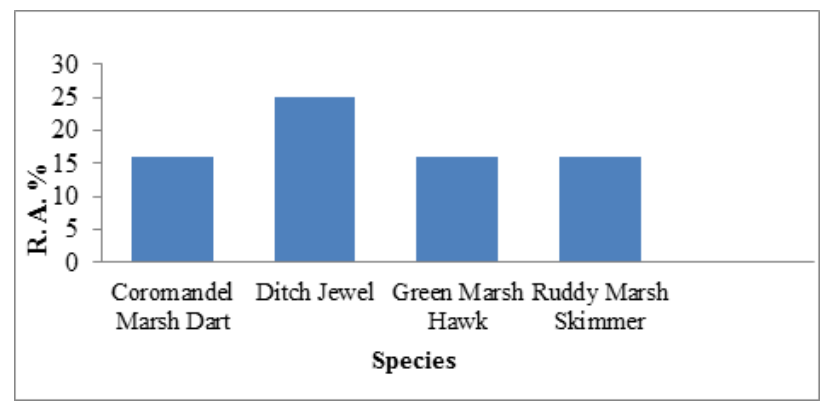

Fig. 2. Relative abundance of dominant Odonates species at Lingda.

Relative abundance (\%) of two suborders of odonata at weekly interval

Both the suborders Anisoptera (dragonfly) and Zygoptera (damselfly) showed similar trend of population fluctuation during the study (Fig. 3). As both the suborders are season specific and have similar breeding requirement in wetlands, they showed similar trend of population fluctuations.

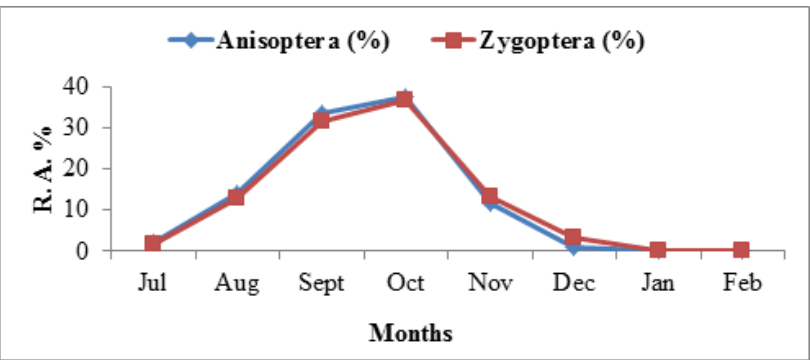

Fig. 3. Relative abundance (\%) of two suborders of Odonata at monthly interval (Population fluctuations - Total number of Anisoptera -2348 and Zygoptera-1402 expressed as R.A. in paddy crop ecosystem).

\section{Presence and index of importance of odonate species at Lingda}

In twenty five weeks study, species like Coromandel Marsh Dart, Ditch Jewel, Green Marsh Hawk, Common Blue Damselfly and Senegal Golden Dartlet were present over eighty percent of time period. The Ruddy Marsh Skimmer was present in eighteen weeks (72\%) period. Four spe- 
cies were present for less than fifty percent of time period and the same also had low relative abundance. The species which showed presence over longer period also had high relative abundance value. Hence, index of importance (I \%) for such species was also high. Based on the value of index of importance, each species was given rank (Table 5).

In the present, study families Libellulidae in Anisoptera and Coenagrionidae in Zygoptera were more diverse families in terms of the number of species. Similar findings have already been reported by some investigators. Ghahari et al. (2009) and Anbalagan et al., (2013) have reported that families Libellulidae and Coenagrionidae were dominant in terms of number of species in rice fields in Iran and Tamilnadu, India, respectively. Kumar and Mitra (1998) reported that family Libellulidae was represented by high number of species (18 species) among a total collection of 42 species from Sahstradhara, Dehra Dun.

Several investigators have reported that dragonflies and damselflies are very common in rice agroecosystem. Kandibane et al., (2003) have recorded 12 species of Odonata under three families in rice fields of Madurai, Tamil Nadu. In the present work the number of species and families recorded in rice fields were much higher compared to all earlier studies (Gunathilagaraj et al., 1999; Kandibane et al., 2003; 2005; Anbalagan et al., 2013; Sathe and Shinde, 2014).
The diversity and distribution of insects may be influenced by type of ecosystems and climate. In the present study the species richness and total abundance of Odonata were high in fish farm compared to rice ecosystem and village pond. However, uniform population dynamics trend on three microhabitats prove the same. Similar result was published by Anbalagan et al. (2013).

This study has certainly improved our knowledge absent odonate diversity in paddy crop agroecosystem. Community structure and population dynamics are all together new studies and the results should be correlated with similar studies on insect pests of paddy (their prey).

In the present study the Shannon index was higher in rice field than fish farm and village pond. Anbalagan et al. (2013) reported that the Shannon index was higher in vegetable fields than rice fields. Climatic factors are also affects the odonates population. Odonate population increases with increases the temperature.

\section{ACKNOWLEDGEMENT}

We are thankful to Dr. S. S. Talmale, ZSI, Jabalpur for confirming identification of Odonates.

Table 5. Presence $(0 \%)$ and index of importance of odonate species on the aquatic environment of Lingda village

\begin{tabular}{|c|c|c|c|c|c|c|c|c|c|}
\hline \multirow{2}{*}{$\begin{array}{l}\text { Sr. } \\
\text { No. }\end{array}$} & \multirow[t]{2}{*}{ Species } & \multicolumn{4}{|c|}{ Present in 25 Weeks } & \multirow[t]{2}{*}{$\% \mathrm{O}$} & \multirow[t]{2}{*}{$\%$ R.A. } & \multirow{2}{*}{$\begin{array}{l}\text { Index of Impor- } \\
\text { tance (I \%) }\end{array}$} & \multirow[t]{2}{*}{ Rank } \\
\hline & & Paddy field & Village pond & Fish farm & $\begin{array}{l}\text { Overall } \\
\text { landscape }\end{array}$ & & & & \\
\hline 1 & Ceriagrion coromandelianum & 18 & 21 & 21 & 22 & 88 & 15.98 & 51.99 & 02 \\
\hline 2 & Enallagma cyathigerum & 10 & 08 & 13 & 16 & 64 & 04.27 & 34.13 & 07 \\
\hline 3 & Ischnura aurora & 03 & 00 & 00 & 03 & 12 & 00.50 & 06.25 & 16 \\
\hline 4 & Ischnura elegans & 02 & 02 & 03 & 04 & 16 & 00.73 & 08.36 & 14 \\
\hline 5 & Ischnura senegalensis & 12 & 12 & 20 & 20 & 80 & 08.33 & 44.16 & 04 \\
\hline 6 & Pseudagrion microcephalum & 09 & 14 & 12 & 16 & 64 & 06.13 & 35.06 & 06 \\
\hline 7 & Pseudagrion rubriceps & 00 & 02 & 02 & 04 & 16 & 00.81 & 08.40 & 13 \\
\hline 8 & Ictinogomphus rapax & 00 & 01 & 03 & 03 & 12 & 00.16 & 06.08 & 17 \\
\hline 9 & Acisoma panorpoides & 00 & 00 & 07 & 07 & 28 & 01.02 & 14.51 & 09 \\
\hline 10 & Brachythemis contaminata & 19 & 22 & 20 & 22 & 88 & 24.76 & 56.38 & 01 \\
\hline 11 & Crocothemis servilia & 17 & 15 & 17 & 18 & 72 & 15.61 & 43.80 & 05 \\
\hline 12 & Diaplacodes trivialis & 06 & 02 & 00 & 06 & 24 & 01.15 & 12.57 & 11 \\
\hline 13 & Orthetrum luzonicum & 04 & 00 & 04 & 06 & 24 & 00.86 & 12.43 & 12 \\
\hline 14 & Orthetrum sabina & 17 & 17 & 20 & 21 & 84 & 16.37 & 50.18 & 03 \\
\hline 15 & Pantala flavescens & 02 & 05 & 03 & 07 & 28 & 00.65 & 14.32 & 10 \\
\hline 16 & Rhyothemis variegata & 02 & 00 & 03 & 04 & 16 & 00.29 & 08.15 & 15 \\
\hline 17 & Trithemis pallidinervis & 08 & 03 & 07 & 12 & 48 & 02.36 & 25.18 & 08 \\
\hline
\end{tabular}




\section{REFERENCES}

Alonso Mejia A, Marquez M. 1994. Dragonfly predation on butterflies in a tropical dry forest. Biotropica 26: 341-344.

Anbalagan V, Paulraj MG, Ignacimuthu S. 2013. Odonata diversity (Insecta: Arthropoda) in rice and vegetable fields in a north-eastern district of Tamil Nadu, India. J Res Bio. 3(4): 977-983.

Bonhof ML, Overholt WA, Van huis A, Polaszek A. 1997. Natural enemies of cereal stem borers in east Africa: A review. Insect Sci Applic. 17: 19-35.

Datta SK, Kush GS. 2002. Improving rice to meet food and nutrient needs: Biotechnology approaches. J Crop Prod. 6: 229-247.

Emiliyamma KG, Radhakrishnan C, Palot MJ. 2005. Pictorial handbook on common dragonflies and damselflies of Kerala. Zool Surv India, Kolkata.

Fraser FC. 1933, 1934, 1936. The fauna of British-India including Ceylon and Burma, Odonata. London: Taylor and Francis Ltd.

Ghahari H, Tabari M, Sakenin H, Ostovan H, Imani S. 2009. Odonata (Insecta) from Northern Iran, with comments on their presence in rice fields Mun Ent Zool. 4(1): 148-154.

Gunathilagaraj K, Soundarajan RP, Chitra N, Swamiappan M. 1999. Odonata in the rice fields of Coimbatore. Zoos' Print J. 14(6): 43-44.

Heinrichs EA. 1994. Biology and management of rice insects. Wiley Eastern Ltd, IRRI.

Kandibane M, Mahadevan NR, Gunathilagaraj K. 2003. Odonata of irrigated rice ecosystem of Madurai, Tamil Nadu. Zoo's Print J. 18: 1155-1156.

Kandibane M, Raguraman S, Ganapathy N. 2005. Relative abundance and diversity of Odonata in an irrigated rice field of Madurai, Tamilnadu. Zoo's Print J. 20(11): 2051-2052.

Khan ZR, Litsinger JA, Barrion AT, Villanueva FFD, Fernandez NJ, Taylor LD. 1991. World bibliography of rice stem borers 1974-1990. International Rice Research Institute and International Centre of Insect Physiology and ecology.
Krebs CJ. 1975. Ecological experimental analysis of distribution and Abundance. Harper and Row, New York.

Kumar A, Mitra A. 1998. Odonata diversity at Sahastredhara (Sulphur springs), Dehra Dun, India. with notes on their habitat ecology. Fraseria 5(1/2): 37-45.

Mohyuddin AI. 1990. Biological control of Chilo spp in maize, sorghum, and millet. Insect Sci Applic. 11: 721-732.

Nair MV. 2011. Dragonflies and Damselflies of Orissa and Eastern India. Wildlife Organization, Forest and Environment Department, Government of Orissa. p. 252.

Obrtel R, Holisova V. 1974. Trophic niches of Apodemum flavicolis and Clethrionomys glareolus in a low-land forest. Acta Sci Nat Brno. 8(7):1-37.

Prasad M. 2004. Insecta: Odonata. pp. 19-40. In: Fauna of Gujarat. State Fauna Series, 8 (Part 2), (Director-ZSI, Ed.). Zool Surv India, Kolkatta.

Rathod DM, Dholu SG, Parasharya BM, Mistry VS, 2016a. Odonate diversity of a Wetland of National Importance Pariej. Jalaplavit. 6(3): 6-15

Rathod DM, Parasharya BM, Talmale SS. 2016b. Odonata (Insecta) diversity of southern Gujarat, India. J Threat Taxa 8(11): 9339-9349.

Rathod DM, Parasharya BM. 2014. Predatory potential of Bradinopyga geminata (Rambur) nymph on mosquito larvae under laboratory condition. Trends in Biosci. 7 (24): 4426-4428.

Rathod DM, Parasharya BM. 2015. Feeding potential of adult dragonflies, Pantala flavescens, Brachythemis contaminata and Bradinopyga geminata (Anisoptera: Libellulidae) on insect pests under laboratory condition. J Biol Control 29(2): 85-88.

Rathod DM, Patel JR, Mistry VS, Parasharya BM, Talmale SS. 2016c. Odonate diversity of Dang forest, a Western ghat extension of Gujarat, India. Adv Life Sci. 5(1): 5302-5310.

Rohmare VB, Rathod DM, Dholu SG, Parasharya BM, Talmale SS. 2015. An inventory of Odonates of Central Gujarat, India. J Threat Taxa 7(11): 7805-7811. 
Sathe TV, Shinde K. 2014. Biodiversity, abundance and prey status of Odonates from paddy ecosystemof Kolhapur district, India. Ind J Appl Res. 4(9): 4-6.

Shannon CE. 1948. A mathematical theory of communication. Bell System Tech J. 27: 379-423.

Siregar AZ, Rawi CSM, Nasution Z. 2010. Abundance and diversity of Odonata in upland rice field at Manik Rambung, North of Sumatera Proceedings of the 7th IMT-GT UNINET and the 3rd International PSU-UNS Conferences on Bioscience; p. 55-61.

Smallshire D, Beynon T. 2010. Dragonfly monitoring scheme manual. British Dragonfly Society, UK.
Subramanian KA. 2009. Dragonflies of India-A field guide. Vigyan Prasar, Department of Science and Technology, New Delhi.

Subramanian KA. 2014, version 2.0. A checklist of Odonata (Insecta) of India. Zool Surv India. Kolkata, India. p. 31.

Tiple A, Paunikar DS, Talmale SS. 2012. Dragonflies and damselflies (Odonata: Insecta) of tropical forest research institute, Jabalpur, Madhya Pradesh, Central India. J Threat Taxa 4(4): 2529-2533. 